UDC 66.01.52:66.012.1

\title{
BLOCK-SCHEME FOR CONTINUOUS CONTROL OF INDUSTRIAL PROCESS DEHYDROGENATION OF ISOBUTANE TO ISOBUTYLENE
}

\author{
R.A.Melikov, F.A.Guseynova, A.S.Guseynov \\ M.Nagiyev Institute of Catalysis and Inorganic Chemistry, NAS of Azerbaijan \\ chem@kqki.science.az \\ Received 03.06.2020 \\ Accepted 21.06.2020
}

\begin{abstract}
The method of continuous control of technological indicators of dehydrification process is proposed. The density and thermal conductivity of the contact gas isobutane is measured using the data from the measurement of the density and thermal conductivity of the contact gas with a computer.
\end{abstract}

Keywords: density sensors, heat conductivity sensors, electronic computer.

doi:

\section{Introduction}

Catalytic dehydrogenation of isobutene plays an important industrial role due to the growing demand for isobutene.

Increasing the depth of hydrocarbon raw materials processing has been and continues to be of actual task a challenge for the chemical and petrochemical fields of industry. Ones from the largest are based on polyisobutylene- and butyl-rubbers produced in the process of isobutane dehydrogenation to isobutylene. The industrial companies such as Shell, Gulf and Dow are world's largest isobutylene producers.

To obtain isobutylene there is widely used a promising process of isobutane dehydrogenation in a fluidized bed of IM-2201 catalyst, circulating in reactor-regenerator system.

We hydrocarbon dehydrogenation processes are realized in a fluidized bed with the use of microspherical alumina-chrome catalyst $[1,2]$. The most effective is implementation of the process with a stationary catalyst bed. This process is characterized by high selectivity $(\mathrm{S}=80-90 \%)$ and yield of target product $(\mathrm{A}=40$ $50 \%$ ). However, the possibilities of this process under industrial conditions are not fully realized, mainly due to the operation of the reactor and regenerator system in a non-optimal mode becaus of failure to take into account the presence of the reaction medium and conditions of regeneration on the catalyst activity. The discreteness of these chromatographic analyses prevents optimal process control [3, 4].
The chromatographic methods of contact gas analysis are discrete and require considerable time to evaluate the process parameters. The latter makes it difficult to organize continuous analytical control of the process parameters and eventually - the output of the target product [5].

\section{Purpose of work}

The aim of the work is to increase the efficiency of synthetic rubbers production by way of modernizing isobutylene production technology, organization of high-technological production, optimization technological parameters of microspherical dehydrogenation catalyst production with the use of sensors for contact gas density and thermal conductivity.

The method of analytical control of technological parameters of paraffin hydrocarbons dehydrogenation processes according to the data of contact gas density and thermal conductivity measurement was suggested and implemented in laboratory researches. It was based on the developed automatized system of continuous control and optimum control of the reactorregenerator unit of isobutane dehydrogenation plant. The created system is based on a microcomputer which contains a $\mathrm{P}$ processor, display $\mathrm{D}$, thermal printing TPU devices, communication device with the object USO, digital voltmeter $\mathrm{CE}$, switching unit relay $\mathrm{BR}, \mathrm{CU}$ command device and a special device to control the MC process indicators is presented in Figure 1. 


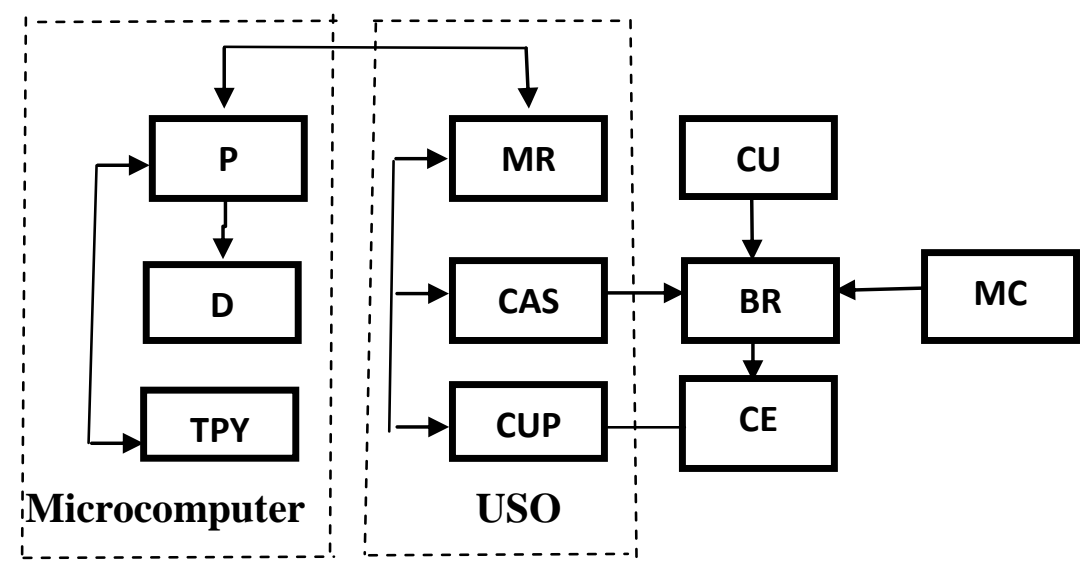

Fig. 1. The structural block diagram of the automatized continuous control system for industrial process of isobutane dehydrogenation.

The control device of the MC consists of a thermostat, a gas preparation panel, an electronic circuit of thermostat control and detectors located in it, as well as recorders of relative readings of detectors of density and thermal conductivity of analyzed gases. The thermostat and the control gas preparation panel of the MC are made in explosion-proof version and are placed in the controlled place of contact gas outlet.

The used detector in terms of thermal conductivity is based on the method of comparison of conductivity of pure comparative gas and binary mixture of comparative gas with the analyzed gas. It consists of a housing with four sensor elements that respond to changes in the thermal conductivity of the environment. Thermosensitive elements are included in the bridge scheme and are heated by a current of $80 \div 100$ $\mathrm{mA}$. Opposite shoulders of the bridge are combined into comparative and measuring cells, through which a comparative gas and a binary mixture flows. When a binary mixture that differs from the comparative gas $\lambda$ in its thermal conductivity flows $\lambda_{2 \mathrm{H}}$ in the measuring cell, an disbalance occurs in the diagonal bridge $\Delta \mathrm{U}_{\lambda}$.

The density detector is a differential weight detector (modified Martin gas scale). The gas scheme of the detector on density consists of three vertical channels connected by horizontal channels, in which tungsten coils or thermistors of hot-wire anemometers are located. In the middle point of the vertical channels are supplied respectively the flows of comparative and ana- lyzed gases. The threads of hot-wire anemometers are included in the scheme of electric measuring bridge and are heated by current passing on them up to the temperature of $100 \div 200^{\circ} \mathrm{C}$. At equality of the density of the analyzed and comparative gases, the electric bridge is in equilibrium. When the density of the analyzed gas increases, the electrical resistance of the hot-wire anemometer threads changes. The equal weight of the electrical measuring bridge is broken and the potentiometer connected to it shows the value of the outlet signal.

In the developed system the pulse mode of input of contact gas into detectors is used: signals from outputs of detectors of DS and HCS accident are registered by secondary devices and are controlled by indicators of $\mathrm{CE}$ connected via ODR with computer. In the latter case, the values of deviation of signals $U_{\rho}^{\max }$ and $U_{\lambda}^{\max }$ DR and DTR from their pre-determined zero levels $U_{\rho}^{0}$ and $U_{\lambda}^{0}$ programmatically are determined. In this case $\rho_{r}, \lambda_{r}$ the calculation is performed according to the expression:

$$
\begin{aligned}
& \rho=K_{1} \cdot \Delta U_{\rho}+\rho_{r}, \\
& \lambda=K_{2} \cdot \Delta U_{\lambda}+\lambda_{r},
\end{aligned}
$$

where $\Delta U_{\rho}=U_{\rho}^{\max }-U_{\rho}^{0} ; \Delta U_{\lambda}=U_{\lambda}^{\max }-U_{\lambda}^{0} ; K_{1}$, $K_{2}$ - calibration coefficients of detectors; $\rho_{r}, \lambda_{r}$ density and thermal conductivity of the gas carrier.

The system provides the procedure of periodic calibration of detector scales and correc- 
tion of calibration coefficients $K_{1}$ and $K_{2}$. For this purpose the reference gases carbon dioxide (ET.1) and its 50\% mixture with hydrogen (ET.2) are used, which have values $\rho_{\mathrm{r}}, \lambda_{\mathrm{r}}$ lie within the working ranges of measurement $\rho_{\mathrm{r}}$, $\lambda_{\mathrm{r}}$ contact gas. Accurate calculation of $K_{1}$ and $K_{2}$ values included in (1 and 2) in these cases is performed using the following expressions:

$$
\begin{gathered}
K_{1}=\frac{\rho_{1}-\rho_{2}}{\Delta U_{\rho_{1}}-\Delta U_{\rho_{2}}}, \\
K_{2}=\frac{\lambda_{1}-\lambda_{2}}{\Delta U_{\lambda_{1}}-\Delta U_{\lambda_{2}}} .
\end{gathered}
$$

where $\rho_{1}, \lambda_{1}$ and $\rho_{2}, \lambda_{2}$ - the density and thermal conductivity of the first and second reference gases, respectively; $\Delta U_{\rho}, \Delta U \lambda_{1}$ and $\Delta U \rho_{2}$, $\Delta U \lambda_{2}$ - the relative deviation of the readings of the DS and HCS the accident when passing through them, respectively, the first and second reference gases.

Sequential supply to the measuring and comparing chambers of DS and HCS contact and reference gases is provided according to the specified time schedule introduced in the computer program, which provides the frequency of calibration of DS and HCS accident.

The information supplied to the computer from the MC is used to calculate the conversion $\alpha$, selectivity $S$ of the target product output value with the subsequent printing of the calculation data. When the system operates in the operator's process control mode, the computer polls the output of density and thermal conductivity detectors with a 20-minute interval, calibrates the scale of detectors $\rho_{\mathrm{r}}, \lambda_{\mathrm{r}}$ calculates the degree of conversion $\alpha$, selectivity $S$, the output value of the target product $A$ with their values for printing:

$$
\begin{aligned}
& \alpha=a \rho+b, \\
& S=c \rho_{0}+d, \\
& \mathrm{~A}=\alpha \cdot S .
\end{aligned}
$$

According to the developed program the whole cycle includes 12 measurements and is designed for 4 hours, i.e. 2 cycles in 8 -hour shift. The program is written in Assembler, where it guarantees the highest speed of information processing: its algorithm is shown in Figure 2.
After starting the program the operator in the dialog mode of the machine records in its RAM all the data needed to calculing the values of $\alpha$ and $S$, namely the values of constants $a, b$, $c, d$ of equations $(3,4)$, as well as the values of density and thermal conductivity of hydrogen, carrier gas, reference gases.

After the initial data have been recorded in the RAM, the whole system is started by the CR "Calibration" command typed on the display keyboard; it is possible to switch to direct measurements by the command of the AK "Analysis" $\rho_{\mathrm{r}}, \lambda_{\mathrm{r}}$, if the automatic calibration of the secondary device scales was made beforehand, i.e. after the first cycle of 12 measurements.

Performing the command "Calibration", the computer through the switch of analog signals CAS includes an intermediate relay in the relay unit BR, which, in turn, includes valves blocking the access of contact gas in the dosing loops of the clans, thereby directing the flow of the first reference gas (ET.1) in the specified loops.

The computer then proceeds to the execution of the "Analysis" subprogramme. This program begins with a pause of 2 minutes, which is necessary for complete washing out of traces of contact gas from the dosed out loops of dosing valves and chambers of detectors $\rho_{\mathrm{r}}, \lambda_{\mathrm{r}}$. At the end of the pause the computer through the CAS module and the BR relay unit connects the digital voltmeter of $\mathrm{CE}$ to the secondary density detector, and through the digital measuring instrument module of the DSP and the relay unit $\mathrm{BR}-$-exit $\mathrm{CE}$ to its input. Thus, a value which is an average of three times the zero level measurement is recorded in the computer RAM. Then, through the CAS module and the relay unit BR Computer includes a valve that provides the input of the analyzed gas into the density detector, and begins measuring the maximum peak of the secondary device. The measurement subroutine $U_{\rho}^{\max }$ is reduced to periodic measurement and memorization of the current values $U_{\rho}^{i}$ and difference calculation $U_{\rho}^{i}-U_{\rho}^{i-1}$; when the difference sign changes to the opposite $U_{\rho}^{i-1}$, the value used as $U_{\rho}^{\max }$. 


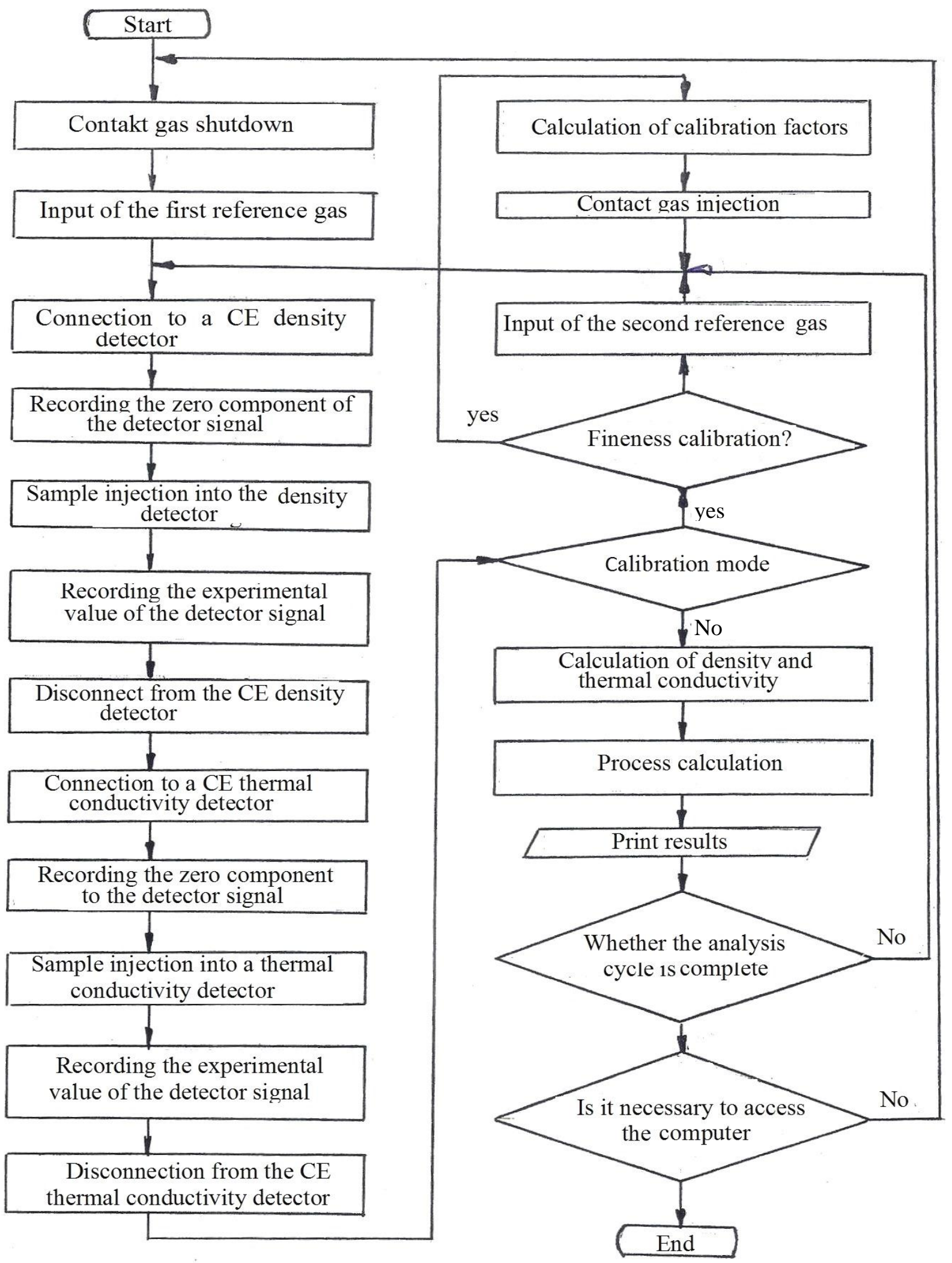

Fig. 2. Block diagram of the algorithm of continuous control of technological parameters of isobutane dehydrogenation process. 
After switching off the valve, the computer connects the DC to the secondary device output of the thermal conductivity detector $\lambda$, measures the zero level of the detector signal $U_{\lambda}^{0}$ and and repeats the same cycle of finding the values $U_{\lambda}^{\max }$ with record valnes $U_{\lambda}^{0} \mathbf{и}$ $U_{\lambda}^{\max }$ in the RAM as well.

Following the program, the computer supplies the second ET.2 reference gas to the detectors by means of valves, and then, according to the "Analysis" sub-program, finds the zero and maximum values of the detectors readings. At the end of this part of the program takes place step-by-step calculation of $\Delta U_{1}, \Delta U_{2}$ which is then used to find the calibration values of $K_{1}$ and $K_{2}$.

After the calibration of the detector scales, the contact gas is supplied to the detectors by turning the valves off and the zero and maximum values are determined in the same way $U_{\rho}^{0}, U_{\lambda}^{0}, U_{\rho}^{\max } U_{\lambda}^{\max }$, which are used to calculate the required values of contact gas density and thermal conductivity, $\alpha$ and process $S$ selectivity, and isobutylene output A.

The received information about the technological indexes is displayed on thermal printing devices. Having checked, whether the cycle of measurements (number of analyses $n=12$ ) has not ended, the computer after a 20-minute pause again turns to the subprogramme "Analysis".

After the end of the cycle, the machine interrupts the subroutine and enters into dialogue. It should be noted that the information about $\alpha, S$, A can be supplemented with data on the temperature modes of individual units of the reactor-regenerator unit of the plant, which is fed into the computer from a number of temperature sensors.

The methods of continuous control of technological parameters: of $\alpha$ - conversion process, $S$ - selectivity, isobutane to isobutylene dehydrogenation output A are proposed according to the data of contact gas density $\rho$ and thermal conductivity $\lambda$ measurement. This technique can be used to study the kinetic regularities and heterogeneous-catalytic processes of dehydrogenation of the lowest paraffin hydrocarbons in the chemical and petrochemical industry to increase productivity.

\section{References}

1. Melikov R.A. Metod of optimal control of the reactor-regenerative unit of the process of deodrification of isobutan to isobutilen. Azerb. Chem. J. 2018. No 4. S. 83-85.

2. Nesterov A.M. Isobutane dehydrogenation on modified alumina-chrome catalyst. Cand. diss. on Chemistry. Togliatti State University. 2018. 115 c.

3. Tanler G.P., Tsimerman S.K. Technological scheme of new reactor of dehydrogenation of propane to propylene. RU 2523527C2. 20.07.2014. Bull. № 20.

4. Riazanov Iu.I., Tuchinskii V.R., Grechuha G.I., Tuibarsov Iu.N., Mironov V.A. Sposob upravleniia protcessom degidrirovaniia uglevodorodov v kipiashchem sloe katalizatora. A.s. 1495333 SSSR. B.I. 1989. № 27.

5. Melikov R.A. Metod avtomaticheskogo upravleniia dlia sokhraneniia aktivnosti katalizatora $\mathrm{v}$ reaktornoregeneratornoi sisteme. Azerb. him. zhurn. 2015. № 3. S. 121-123.

\section{IZOBUTANIN İZOBUTILENO DEHIDROGENLOŞMOSININ SONAYE PROSESININ FASILISSIZ IDDARכ OLUNMASININ BLOK SXEMI}

\section{R.Ө.Məlikov, F.A.Hüseynova, Ә.S.Hüseynov}

İzobutanın izobutilenə dehidrogenləşmə prosesində kontakt qazının sıxlıq $\rho$, istilikkeçirmə $\lambda$ göstəricilərinin və elektron hesablayıcı maşının iştirakı ilə texnoloji prosesin fasiləsiz idarə metodu tövsiyə edilmişdir.

Açar sözlor: sıxlıq, istilikkeçirmə, elektron hesablayıcı maşın.

\section{БЛОК-СХЕМА НЕПРЕРЫВНОГО КОНТРОЛЯ ПРОМЫШЛЕННОГО ПРОЦЕССА ДЕГИДРИРОВАНИЯ ИЗОБУТАНА В ИЗОБУТИЛЕН}

\section{Р.А.Меликов, Ф.А.Гусейнова, А.С.Гусейнов}

Предложена методика непрерывного контроля технологических показателей процесса дегидрирования изобутана по данным измерения плотности $\rho$ и теплопроводности $\lambda$ контактного газа с применением ЭВМ.

Ключевые слова: датчики плотности, теплопроводности, электронно-вычислительная машина. 